Journal An-Nafs: Kajian Penelitian Psikologi

https://ejournal.iai-tribakti.ac.id/index.php/psikologi

e-ISSN: 2549-6166

p-ISSN: 2528-0600

DOI: $10.33367 /$ psi.v5i1.1042

\title{
WUDU AS ISLAMIC PSYCHOTHERAPY TO IMPROVE SLEEP QUALITY IN YOUNG WOMEN
}

\author{
Iredho Fani Reza \\ iredhofanireza_uin@radenfatah.ac.id \\ UIN Raden Fatah Palembang
}

\begin{abstract}
Many previous studies have tried to find therapies in dealing with poor sleep quality in women. Where many researchers find that women are more likely to have poor sleep quality than men. Therefore, this study is to prove the effectiveness of wudu as a psychotherapy for sleep quality. This research is a quantitative pre-experimental research with One-Group Pretest-Posttest Design. Research respondents were determined by purposive sampling technique $(N=17)$ all of them were young women who are students at one of the tertiary institutions in Indonesia. To measure sleep quality using the Sleep Quality Scale developed by Yi, Shin, and Shin (2006). Data analysis techniques using the Paired Samples T-Test technique. From the test results get a value $p=0.031$ ( $p$ <0.05). This study found that wudu therapy is effective in improving sleep quality in young women by focusing on increasing satisfaction with sleep which consists of three indicators namely: 1) Satisfaction Level with overall sleep; 2) Sleep tight; 3) Enough sleep.
\end{abstract}

Keyword: Wudu therapy, Sleep quality, Islamic psychotherapy

\section{INTRODUCTION}

As a human who lives on this earth Certainly have hopes and desires to be achieved. Various kinds of activities and efforts carried out by every human being to realize their hopes and desires. In the perspective of Islamic Psychology, that Allah SWT in the Qur'an has given a special time in the morning or afternoon to realize hopes and desires through these efforts and activities (QS. 78:11; QS. 25: 47; QS. 30: 23. Taufiq, 2013). And there is time to rest that has been determined in the Qur'an, namely at night, when it has finished its activities and business in the morning or afternoon (QS. 28: 73; QS. 6: 60 \& 96; QS. 10: 67; QS. 40: 61. Taufiq, 2013).

In this article, the focus of the study's theme is the quality of sleep in a person. Having a good quality sleep has many important positive impacts on humans in carrying out life and health (Royal Society for Public Health, 2016). One interesting theme of sleep studied in a psychological study is the quality of sleep. What is sleep quality?

Based on researchers' search results, the term "sleep quality" through related journal articles. That the definition of sleep quality cannot be ascertained to be the most correct 
definition by every researcher, doctor, academic or community (Ohayon et al., 2016). Some researchers reveal the definition of sleep quality. As according to Ohayon (2016) sleep quality is a sleep process that is considered valuable. Furthermore according to Harvey (2008) states that sleep quality is defined by relating to fatigue when waking up and throughout the day, feeling rested and recovering when waking up, and the amount of waking they experience at night.

Kline (2013) defines sleep quality as someone's satisfaction with sleep experiences, integrating aspects of sleep initiation, sleep maintenance, quantity of sleep, and refreshment upon awakening. Furthermore, according to the World Health Organization (2004) the concept of sleep quality varies greatly from one person to another because subjective expectations vary widely and are complex. Therefore, sleep disturbance is related to sleep quality.

Based on several definitions of sleep quality. Experts have a different perspective. In accordance with the perspective of each of the scientific aspects. In this case, researchers try to define sleep quality in a psychological perspective. In this article, sleep quality is defined in a psychological perspective, which is defined as how much a person's level of satisfaction with sleep and how to respond to the sleep problems they experience.

From the research results of researchers, that there are several factors that affect sleep quality including: 1) High calorie food (Lai \& Say, 2013); 2) There are physical and psychological illnesses (Shim \& Kang, 2017); 3) Gender differences between men and women (Burgard \& Ailshire, 2013).

The focus of the study in this article is to highlight one of the factors that can be a determinant of sleep quality in humans, namely gender differences, male and female. Based on the results of previous studies on gender differences between men and women on sleep quality, it shows that the quality of sleep of women is lower than that of men (Burgard \& Ailshire, 2013; Madrid-Valero, Martínez-Selva, Ribeiro do Couto, Sánchez-Romera, \& Ordoñana, 2017; Mallampalli \& Carter, 2014; Pereira et al., 2012). From several studies found by researchers, it appears that the tendency of gender differences also affects one's self quality. Especially in women who tend to have poor sleep quality.

According to Yi, Shin and Shin (2006) that there are six factors of sleep quality, including: 1) Daytime Dysfunction; 2) Restoration After Sleep; 3) Difficulty in Falling Asleep; 4) Difficulty in Getting Up; 5) Satisfaction With Sleep; 6) Difficulty in Maintaining Sleep.

Based on the results of preliminary interviews conducted by researchers from several groups of young female subjects who are students who are students at one of the state Islamic religious colleges in Indonesia. Confess that experiencing problems with sleep. Starting from 
sleeping late at night and having trouble sleeping.

In overcoming sleep disorders to improve quality in a person. Many ways are done by academics as an effort to produce ways to improve sleep quality. Various kinds of therapies are also tried to improve sleep quality. In conventional psychological therapy approaches most used Behavioral Therapy. (Vallières, Roy, Bastille-Denis, Claveau, \& Simon, 2015) and Cognitive Behavioral Therapy (Robinson, Smith, Segal, \& Segal, 2019).

In this case, researchers offer an approach in overcoming sleep disorders to improve quality by using one form of Islamic Psychotherapy method. Islamic psychotherapy is a technique for the prevention and treatment of psychiatric disorders originating from the problems of human life by using a combination of religious approaches and psychological approaches in the perspective of Islamic religion that can be applied alone or by a psychotherapist to clients (Reza, 2016).

Rothman (2018) revealed that there was a dearth of collective understanding of how the Islamic worldview could be practically and effectively integrated into psychotherapy, as well as a lack of understanding of how Islam's orientation towards psychology might also have something to offer to more people outside them.

In this case, the application of Islamic psychotherapy is not yet fully accepted by all academic communities and practitioners in the field of psychology. This further study is needed to build an Islamic psychotherapy framework as one of the psychotherapy approaches that can be accepted by everyone.

Rothman and Coyle (2018) offer how to build an initial framework in building Islamic psychotherapy. According to Rothman and Coyle revealed that to build a framework of Islamic psychology and psychotherapy requires an understanding of the human soul that characterizes the Islamic tradition. The aspects of the mechanism for soul development are potential foundations for Islamic theories of human psychology and have special relevance for Islamic approaches to psychotherapy.

Furthermore, in a study that researchers have done that there are three forms of Islamic psychotherapy approach, namely: 1) Psychotherapy through faith; 2) Psychotherapy through worship; 3) Psychotherapy through ruqyah (Reza, 2016). In this case, researchers specialize psychotherapy through worship as a therapy of sleep quality. Because of that worship too many, researchers have redefined the form of the method of wudu as Islamic psychotherapy.

Researchers call this therapy for sleep quality with wudu therapy for sleep quality which is part of psychotherapy through worship. In the perspective of Islamic psychology, wudu is a form of worship to Allah that aims to purify the body and mind by washing water 
to some predetermined body parts, which are carried out before the prayer or before carrying out daily activities. The wudu provisions and recommendations are contained in QS. AlMa'idah [5]: 6 (Reza \& Magfiroh, 2016).

The basis for applying the form of Islamic psychotherapy methods through worship, wudu therapy for sleep quality is based on the benefits of wudu which has two benefits: 1) Physiological benefits; 2) Psychological benefits (Reza, 2016). Both aspects of human beings are the basic assumptions of the application of psychotherapy to sleep quality for the subjects in this study, namely young women.

Wudu as a psychotherapy has been proven by several previous researchers. Like the research conducted by Hariawan, Haryanto, Ulfiana (2017) found that water splashes and massage on ablution can reduce muscle tension and make the body relax and can be used as a relaxation therapy to improve sleep quality in the elderly with insomnia.

Research conducted by Sabra (2018) found that wudu had a good effect on maintaining individual hygiene in the form of protection against bacterial infections. Furthermore, Idris, Wahab dan Yusoff (2017) found that wudu had an impact in controlling emotional distress on students.

Based on the phenomena and results of previous studies. Researchers are interested in conducting further research with the research hypothesis whether there is an effect of wudu as Islamic psychotherapy on sleep quality in young women.

\section{METHOD}

This research is a type of quantitative research with pre-experimental research design. The pre-experimental design used is the One-Group Pretest-Posttest Design. Cresswel revealed that This design includes a pretest measure followed by a treatment and a posttest for a single group (Creswell, 2014).

Information

\begin{tabular}{llllll}
\hline Group A & 01 & ---- & X & $-\cdots$ & 02 \\
\hline
\end{tabular}

$\begin{array}{ll}\text { Group A } & \text { : Experiment Group } \\ 01 & \text { : Pretest } \\ ---\mathrm{X}---- & : \text { Treatment } \\ 02 & \text { : Posttest }\end{array}$

The population in this study is young women who are students in one of the state Islamic religious colleges in Indonesia. Researchers gathered a class of students in 2019 totaling 31 young women as the population in this study. 
Iredho Fani Reza | Wudu as Islamic Psychotherapy

From 31 young women, the researcher determined the respondents who would become the study sample. Because this research is a type of experimental research. The rules for determining the number of samples in this study use the opinion of Creswell (2012) which revealed that the number of respondents in the experimental study was 15 respondents.

The sampling technique in this study uses a purposive sampling technique (Cozby \& Bates, 2015). The criteria of this research sample include: 1) Research respondents who tend to have sleep problems. Evidenced by the results of data retrieval with the Sleep Quality Questionaire (SQS) developed by Espie, Kyle, Hames, Gardani, Fleming, Cape (2014); 2) Willing to be a respondent in research.

Based on purposive sampling techniques and rules used in determining the number of samples in this study. Then the research respondents who met the criteria amounted to 17 research respondents.

The variables in this study are divided into two research variables as follows:

Independent variable $(\mathrm{Vx}) \quad$ : Wudu Therapy

Dependent variable (Vy) : Sleep Quality

\begin{tabular}{lll}
\hline Vx (Wudu Therapy) & Vy (Sleep Quality) \\
\hline
\end{tabular}

Wudu therapy is a form of Islamic psychotherapy method through worship that is applied using water media that have been determined based on the interpretation of QS. AlMa'idah [5]: 6. Sleep quality is how much a person is satisfied with sleep and how they respond to sleep problems.

Measurements in this study use the Sleep Quality Scale (SQS) developed by Yi, Shin, and Shin (2006) which revealed six sleep quality factors consisting of 28 item scales. Explanation of measurement in this research in detail as follows:

Table 1. Blue Print Sleep Quality Scale

\begin{tabular}{clll}
\hline No & \multicolumn{1}{c}{ Factors Sleep Quality } & \multicolumn{1}{c}{$\begin{array}{c}\text { Item Distribution } \\
\text { Number }\end{array}$} & Total Item \\
\hline 1 & Daytime Dysfunction & $1,2,3,4,5,6,7,8,9,10,11$, & 12 Item \\
\hline 2 & Restoration After Sleep & 12 & 4 Item \\
\hline 3 & Difficulty in Falling Asleep & $17,14,15,16$ & 4 Item \\
\hline 4 & Difficulty in Getting Up & $21,22,23$ & 3 Item \\
\hline 5 & Satisfaction with Sleep & $24,25,26$ & 3 Item \\
\hline 6 & Difficulty in Maintaining Sleep & 27,28 & 2 Item \\
\hline Total Item & & 28 Item \\
\hline
\end{tabular}


The response to the answer from the Likert scale used there are four response answers and each answer is given a rating score ( $\mathrm{few}=0$, sometimes $=1$, often $=2$, almost always $=3$ ). Scores on items in factors 2 and 5 have to be reversed before all the scores are summed. The Sleep Quality Scale (SQS) used in this study, as a valid and reliable instrument for a comprehensive assessment of sleep quality. Because Cronbach's alpha coefficient already has 0.92 for internal consistency and the correlation coefficient is 0.81 for re-test reliability (Yi et al., 2006).

Furthermore, the intervention given in this study is Wudu Therapy for Sleep Quality. In the implementation of intervening the same as the implementation of wudu as worship before the implementation of prayer in an Islamic perspective based on the interpretation of QS. Al-Ma'idah [5]: 6. Provision of wudu therapy interventions carried out by research respondents: 1) Before going to sleep at night; 2) In the morning before carrying out daily activities; 3 ) And endeavored to keep themselves to remain in a holy state by wudu. This intervention was carried out for one week.

Research Flow. This research lasted for five months from October 2019 to January 2020. It consisted of the stages of preparing a research proposal, research preparation, research implementation, data processing and preparation of research reports. In the research preparation stage, by compiling a research measurement and experimental module for research interventions.

In conducting the research, the implementation of the pretest begins by providing a Sleep Quality Scale (SQS) to the respondents of the research that has been determined. The intervention will be continued in the form of: 1) transferring knowledge in the form of wudu as Islamic psychotherapy, the basis of its implementation, the procedures for its implementation, the benefits of its implementation; 2) Implementation of the intervention for one week, respondents were asked to carry out wudu therapy. After giving treatment, the next step is implementing posttest by giving Sleep Quality Scale (SQS) again. The final stage is data processing and preparation of the research report as a research article.

Data Analysis Method. In analyzing the data in this study, researchers used the help of the Statistical Measurement Program namely JASP (Jeffrey's Amazing Statistics Program) version: 0.8.5.1 (Bogart et al., 2018). The research data analysis technique used was using the Paired Samples T-Test technique (Goss Sampson, 2018). 
Iredho Fani Reza | Wudu as Islamic Psychotherapy

RESULT

Level of Sleep Quality ff The Respondent. From 17 young women research respondents. Researchers conducted a sleep quality categorization analysis. From the results of categorization analysis, it can be seen the level of sleep quality of respondents as follows:

\begin{tabular}{|c|c|c|c|}
\hline Score & Level & $\mathrm{N}$ & $\%$ \\
\hline$X>32$ & High & 3 & $18 \%$ \\
\hline $19-32$ & Average & 10 & $59 \%$ \\
\hline$X \leq 18$ & Low & 4 & $23 \%$ \\
\hline \multicolumn{2}{|c|}{ Total } & 17 & $100 \%$ \\
\hline
\end{tabular}

From the results of the categorization test it was found that out of 17 young women study respondents, who were at a high level of sleep quality as many as 3 people (18\%), were at an average level of sleep quality of 10 people (59\%), were at a low level of sleep quality as many as 4 people (23\%).

Normality Test Data. Before the implementation of the hypothesis test in this study. Are there differences before and after the administration of wudu therapy interventions on sleep quality in young women. Researchers conducted a normality test data analysis using the Shapiro-Wilk technique using the help of the JASP statistical program (Jeffrey's Amazing Statistics Program) version: 0.8.5.1. The normality test data can be seen in the table below:

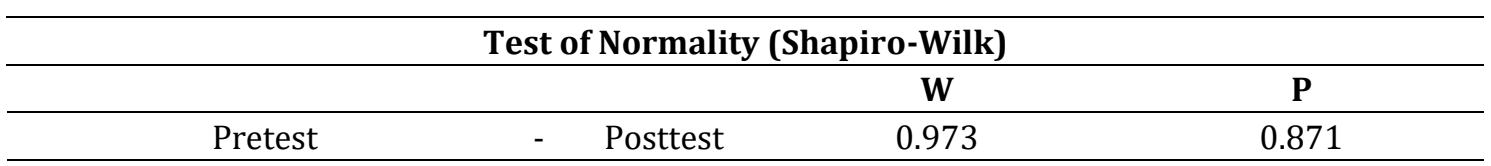

Note. Significant results suggest a deviation from normality

Based on the results of the normality test data analysis, the value of $\rho=0.871$ was obtained. Then the data in this study are stated to be normally distributed because the value $\rho>0.05$ (Reza, 2017).

Hypothesis Testing. Based on the results of hypothesis testing using the Paired Samples T-Test technique with the help of JASP (Jeffrey's Amazing Statistics Program) version: 0.8.5.1, as follows:

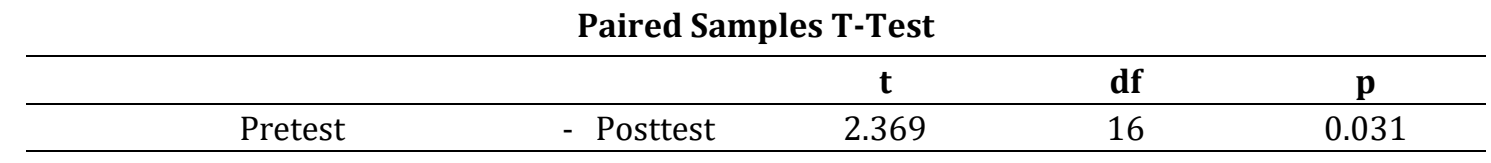

Note. Student's t-test. 
Based on the results of testing using the Paired Samples T-Test technique, the value $\rho=$ 0.031 is obtained. Then it can be interpreted that the value $\rho<0.05$ (Reza, 2017), which means there is a significant difference in the quality of pretest sleep with the quality of posttest sleep after giving wudu therapy interventions.

Furthermore, researchers also conducted further analysis, comparing each dimension of sleep quality factors between before and after the administration of wudu therapy interventions, as follows:

Paired Samples T-Test

\begin{tabular}{ccccc}
\hline & & $\mathbf{t}$ & $\mathbf{d f}$ & $\mathbf{p}$ \\
\hline Pre1 & - Post1 & 0.645 & 16 & 0.528 \\
\hline Pre2 & - Post2 & 1.602 & 16 & 0.129 \\
\hline Pre3 & - Post3 & 0.779 & 16 & 0.448 \\
\hline Pre4 & - Post4 & 1.289 & 16 & 0.216 \\
\hline Pre5 & - Post5 & 4.190 & 16 & $<.001$ \\
\hline Pre6 & - Post6 & -0.131 & 16 & 0.897 \\
\hline
\end{tabular}

Note. Student's t-test.

1 (Daytime Dysfunction); 2(Restoration After Sleep); 3 (Difficulty in Falling Asleep); 4 (Difficulty in Getting Up); 5 (Satisfaction with Sleep); 6 (Difficulty in Maintaining Sleep).

Based on the results of a comparative analysis of each dimension factor of sleep quality. That only one factor that is seen there is a difference between before and after giving Wudu Therapy Intervention $(\rho<0.05)$ Namely Satisfaction with Sleep Factors That Have Three Indicators Namely with value $\rho=0.001$ : 1) Satisfaction Level with Overall Sleep; 2) Sleep Tight; 3) Enough Sleep.

\section{DISCUSSION}

Based on the results of data analysis in this study. It was found that wudu therapy as Islamic psychotherapy can improve sleep quality in young women. Significantly there are differences before giving wudu therapy with after giving wudu therapy to young women.

Why wudu therapy can be a therapy in improving sleep quality in young women. Researchers analyze these findings with two basic benefits of wudu therapy which are physiologically beneficial and have psychological benefits.

First, wudu therapy towards the quality of sleep in young women provides physiological benefits. As stated by the World Health Organization (2004) that Sleep, as a physiological condition, is needed for the well-being of living organisms. Their interactions with daytime activities are very deep and they determine the global balance between these 
two basic conditions: sleep and wake up.

Research conducted by Yasin (2012) found that wudu in the right way can prevent Muslims from various chronic diseases. Furthermore, Irmak research (2014) found that wudu had a role in the health of the human brain. Where with the stages of ablution wash face, oral and nasal cavity, and wet the scalp, ears and nape 4-5 times a day helps the brain stay cool throughout the day. This clearly means that by ablutions cool the head, the brain is healthier.

Secondly, wudu therapy on the quality of sleep in young women provides psychological benefits. Research conducted by Sari (2018) found that wudu is beneficial for physical and psychological health as a succession of character education / mental revolution for future generations of Muslims.

Based on the two benefits of wudu therapy on sleep quality. That between physiological benefits and psychological benefits are related to one another. As the chart below:

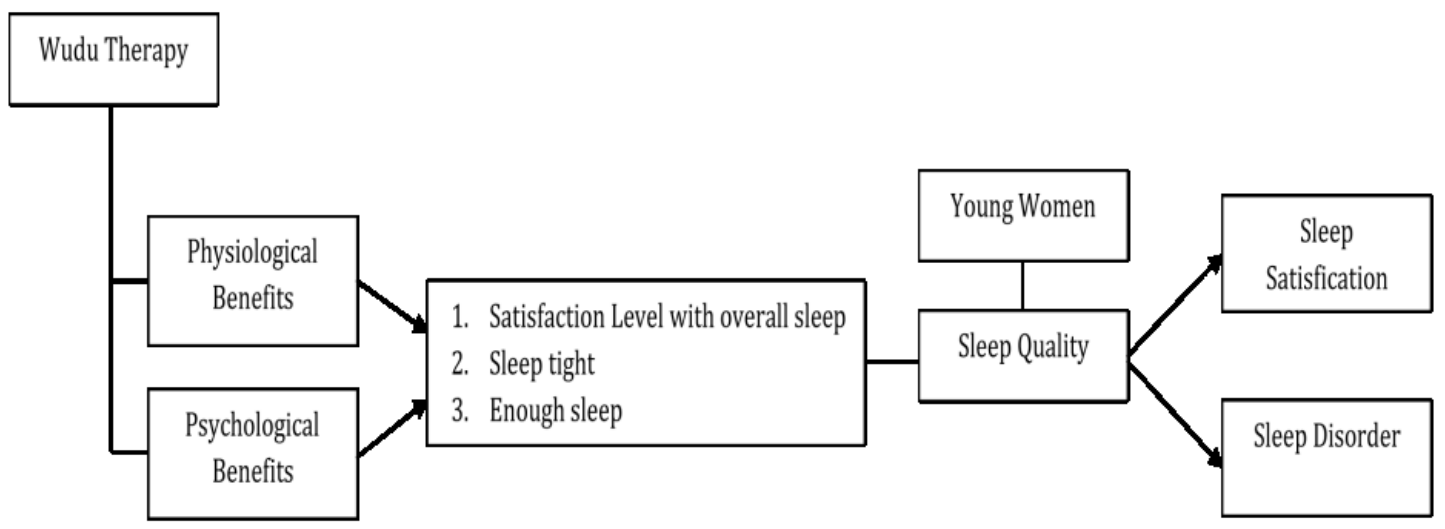

Based on the chart above, that wudu therapy provides two main benefits, namely physiological benefits and psychological benefits for young women. Both of these benefits produce three benefits specifically for sleep quality, namely: 1) Satisfaction Level with overall sleep; 2) Sleep tight; 3) Enough sleep.

When wudu therapy has served as an Islamic psychotherapy for sleep quality, it will increase satisfaction with sleep and reduce sleep disorders. This is because physiological and psychological conditions in humans are related to one another, wudu therapy can provide benefits to these physiological and psychological conditions.

Research conducted by Bhat and Qureshi (2013) found that good physical and emotional health helps our body and mind function properly without pain, anxiety, depression, or discomfort. One method that is ablution which is a good health practice by washing all exposed parts of the body such as hands, feet, face, mouth, nostrils five times a day has a great preventative measure. 


\section{CONCLUSION}

This study found that there was a difference between before giving wudu therapy and after giving wudu therapy to sleep quality in young women. In the sense that wudu therapy is effective in improving sleep quality in young women. Further from the results of a comparative analysis of the six factors of sleep quality, it was found that wudu therapy was more focused on improving Satisfaction with Sleep which consisted of three indicators namely increasing: 1) Satisfaction Level with overall sleep; 2) Sleep tight; 3) Enough sleep.

Based on the results of this study, researchers provide several recommendations, including: 1) Young women who can choose wudu therapy as a method of dealing with sleep disorders that are experienced or can also be a preventive effort to improve sleep quality; 2) For further researchers, it is recommended to develop wudu therapy as a form of therapy for other variables apart from the quality of sleep, can also prove research on wudu therapy for men; 3) Counselors and therapists can try the wudu therapy approach as a form of Islamic psychotherapy for clients who tend to experience sleep disorders.

\section{ACKNOWLEDGEMENTS}

Researchers say thank you especially to the academic community of the Faculty of Psychology, Universitas Islam Negeri Raden Fatah Palembang. Has given the author the opportunity to carry out this research.

\section{REFERENCES}

Anuar, A. I. M., Nubli, A. W. M., \& Yusma, M. Y. N. (2017). The Significant Effect of Wudu' and Zikr in the Controlling of Emotional Pressure Using Biofeedback Emwave Technique. International Journal of Social, Behavioral, Educational, Economic, Business and Industrial Engineering, 1(4).

Bhat, A. M., \& Qureshi, A. A. (2013). Significance of Personal Hygiene from Islamic Perspective. IOSR Journal Of Humanities And Social Science (IOSR-JHSS, 10(5), 35-39. Retrieved from www.Iosrjournals.Org

Bogart, S., Cates, K., Cecire, J., Curtin, D., Czarnowski, D., Deronda, A., ... Varilias, L. (2018). JASP Manual. (Susan A. Nolan's, Ed.). New Jersey: Seton Hall University's.

Burgard, S. A., \& Ailshire, J. A. (2013). Gender and Time for Sleep among U.S. Adults. American Sociological Review, 78(1), 51-69. https://doi.org/10.1177/0003122412472048

Cozby, P. C., \& Bates, S. C. (2015). Methods in Behavioral Research. New York: McGraw-Hill Education.

Creswell, J. W. (2012). Educational research: Planning, conducting, and evaluating quantitative and qualitative research. Educational Research (Vol. 4). https://doi.org/10.1017/CB09781107415324.004

Creswell, J. W. (2014). Research design: qualitative, quantitative, and mixed methods 
approaches (4th Edition). Thousan Oaks: Sage Publication.

Espie, C. A., Kyle, S. D., Hames, P., Gardani, M., Fleming, L., \& Cape, J. (2014). The Sleep Condition Indicator: a clinical screening tool to evaluate insomnia disorder. $B M J$ Open, 4. https://doi.org/10.1136/bmjopen-2013

Goss Sampson, M. A. (2018). Statistical Analysis In JASP: A Guide For Students. Greenwich: Centre for Science and Medicine in Sport University of Greenwich.

Hariawan, H., Haryanto, J., \& Ulfiana, E. (2017). Wudu Improving Sleep Quality on Elderly with Insomnia. In Proceedings of the 8th International Nursing Conference on Education, Practice and Research Development in Nursing (INC 2017). Paris: Atlantis Press. https://doi.org/Atlantis Press

Harvey, A. G., Stinson, K., Whitaker, K. L., Moskovitz, D., \& Virk, H. (2008). The subjective meaning of sleep quality: A comparison of individuals with and without insomnia. Sleep, 31(3), 383-393. https://doi.org/10.1093/sleep/31.3.383

Irmak, M. K. (2014). Medical aspects of ablution and prayer. Journal of Experimental and Integrative Medicine, 4(2), 147. https://doi.org/10.5455/jeim.291213.hp.010

Kline, C. (2013). Sleep Quality. In J. R. Gellman Marc D.and Turner (Ed.), Encyclopedia of Behavioral Medicine (pp. 1811-1813). Inbook, New York, NY: Springer New York. https://doi.org/10.1007/978-1-4419-1005-9_849

Lai, P.-P., \& Say, Y.-H. (2013). Associated Factors of Sleep Quality and Behavior among Students of Two Tertiary Institutions in Northern Malaysia. Med J Malaysia, 68(3). Retrieved from https://www.researchgate.net/publication/237084744

Madrid-Valero, J. J., Martínez-Selva, J. M., Ribeiro do Couto, B., Sánchez-Romera, J. F., \& Ordoñana, J. R. (2017). Efecto de la edad y el sexo sobre la prevalencia de una pobre calidad del sueño en población adulta. Gaceta Sanitaria, 31(1), 18-22. https://doi.org/10.1016/j.gaceta.2016.05.013

Mallampalli, M. P., \& Carter, C. L. (2014). Exploring Sex and Gender Differences in Sleep Health: A Society for Women's Health Research Report. Journal of Women's Health, 23(7). https://doi.org/10.1089/jwh.2014.4816

M Sabra, S. M. (2018). Ablution (Wudu) health benefits (HBs) through comparison nasalcavity (NC) bacterial-content (BC) with gold-standard (GS) at high-altitude (HA) area, Taif, KSA. Journal of Applied Biotechnology \& Bioengineering, 5(6). https://doi.org/10.15406/jabb.2018.05.00160

Ohayon, M., Wickwire, E. M., Hirshkowitz, M., Albert, S. M., Avidan, A., Daly, F. J., ... Vitiello, M. V. (2016). National Sleep Foundation's sleep quality recommendations: first report ir. Sleep Health: Journal of the National Sleep Foundation, 3, 6-19. https://doi.org/10.1016/j.sleh.2016.11.006

Pereira, E. C. A., Schmitt, A. C. B., Cardoso, M. R. A., Pereira, W. M. P., Lorenzi-Filho, G., Blumel, J. E., \& Aldrighi, J. M. (2012). Prevalência da sonolência diurna excessiva e fatores associados em mulheres de 35 a 49 anos de idade do "Projeto de Saúde de Pindamonhangaba" (PROSAPIN). Revista Da Associacao Medica Brasileira, 58(4), 447-452. https://doi.org/10.1590/S0104-42302012000400015

Reza, I. F. (2016). Teori dan Praktik Psikoterapi Islam. Palembang: Noer Fikri Offset. Reza, I. F. (2017). Statistika Psikologi. Palembang: Noer Fikri Offset.

Reza, I. F., \& Magfiroh. (2016). Psikologi Ibadah Peran Ritual Agama Dalam Kehidupan 
Manusia. Palembang: Noer Fikri Offset.

Robinson, L., Smith, M., Segal, R., \& Segal, J. (2019). Therapy for Sleep Disorders. Retrieved from https://www.helpguide.org/articles/sleep/therapy-for-sleepdisorders.htm?pdf $=13846$

Rothman, A. (2018). An Islamic Theoretical Orientation to Psychotherapy. In Islamically Integrated Psychotherapy: Uniting Faith and Professional Practice (pp. 25-56). West Conshohocken: Templeton Press. Retrieved from https://www.researchgate.net/publication/326782305

Rothman, A., \& Coyle, A. (2018). Toward a Framework for Islamic Psychology and Psychotherapy: An Islamic Model of the Soul. Journal of Religion and Health, 57(5), 1731-1744. https://doi.org/10.1007/s10943-018-0651-x

Royal Society for Public Health. (2016). Waking up to the health benefits of sleep Section Page. London.

Sari, D. C. (2018). Wudhu As a Succession of Mental Revolution For Future Generation. Journal of Educational Science and Technology (EST), 4(1), 1. https://doi.org/10.26858/est.v4i1.3775

Shim, J., \& Kang, S. W. (2017). Behavioral Factors Related to Sleep Quality and Duration in Adults. Journal of Lifestyle Medicine, 7(1), 18-26. https://doi.org/10.15280/jlm.2017.7.1.18

Taufiq, M. (2013). Quran in Word Ver 1.3. Taufiq Product.

Vallières, A., Roy, M., Bastille-Denis, E., Claveau, S., \& Simon, T. (2015). Exploring a Behavioural Therapy for Insomnia in Shift Workers. Journal of Sleep Disorders \& Therapy, 4(3). https://doi.org/10.4172/2167-0277.1000202

World Health Organization. (2004). WHO Technical Meeting On Sleep and Health. Bonn Germany.

Yasin, Q. A. F. (2012). Physical And Spiritual Miracles Of Muslims' Ablution. International Journal of Quranic Research, 3(2), 67-83. Retrieved from https://ejournal.um.edu.my/index.php/quranica/article/view/5211/3015

Yi, H., Shin, K., \& Shin, C. (2006). Development of the Sleep Quality Scale. J. Sleep Res, 15, 309316. 